DOI https://doi.org/10.30525/978-9934-26-006-3-19

\title{
ЕКОЛОГІЧНІ ПРОБЛЕМИ ЛІСОВИХ НАСАДЖЕНЬ
}

\author{
Плетюк I. А. \\ студентка 41 Е групи \\ Кременецька обласна гуманітарно-педагогічна академія \\ імені Тараса Шевченка
}

Гурська О. В.

кандидат біологічних наук,

старший викладач кафедри біології, екології та методики їх навчання

Кременецька обласна гуманітарно-педагогічна академія

імені Тараса Шевченка

м. Кременець, Тернопільська область, Україна

Однією з актуальних проблем розвитку людства $€$ забезпечення охорони, раціонального використання та відтворення лісових ресурсів світу. Ліси $є$ глобальним і життєво важливим чинником усього комплексу екологічних систем Землі, оскільки вони характеризуються найвищою інтенсивністю біологічного кругообігу та мають найбільшу органічну масу, значення якої постійно зростає [1].

Ліс - це не тільки природний ландшафт, а й невід'ємна частина національної та світової історії, культури та духовних цінностей суспільства.

Ліси забезпечують існування 50 \% видів наземних екосистем, вони регулюють клімат планети та впливають на гідрологічний режим територій. Лісова продукція важлива не тільки тому, що деревина $€$ відновлюваним ресурсом, здатною до переробки та біологічного руйнування, а тому, що ліси $є$ основою екологічної інфраструктури планети [2].

Тернопільська область - один з регіонів України, розміщений у західній частині Правобережного лісостепу, де ще збереглися сприятливі грунтово-кліматичні умови для життєдіяльності лісових фітоценозів. Однак впродовж останніх років лісові насадження області зазнають впливу численних факторів, що негативно позначається на функціональних показниках та продуктивності лісових масивів [3].

Масове всихання лісових насаджень - екологічне лихо, яке впродовж останніх кілька років стрімко поширюється. Це завдає значної екологічної й економічної шкоди сосновим лісам. Всихають 
також такі цінні породи як дуб, ясен, граб, але найбільше - хвойні: ялина, сосна.

Шкідники лісу (комахи чи хвороби) були завжди. Але якщо певні фактори сприяють їхньому активному розмноженню, то як наслідок знижується продуктивність (якість) насаджень або всихають дерева.

Зазвичай, шкідник дає дві генерації за період, а в умовах подовженого літа (яке ми фактично на сьогодні й маємо) - до 5 генерацій! Кліматичні зміни призводять до аномальних природних явищ (буревій, посухи сприяють виникненню пожеж). Все це у сукупності зі зниженням грунтових вод, зміною гідрорежиму грунту зменшує стійкість лісів і здатність чинити опір патогенам [4].

Переважна більшість шкідників лісу відноситься до класу комах, у меншій мірі шкодять деякі види кліщів і хребетних тварин. Залежно від характеру живлення шкідники лісу підрозділяються на хвоє- i листогризучих (первинних), які пошкоджують здорові деревні рослини; стовбурових (вторинних), що пошкоджують вже ослаблені дерева; кореневих, або грунтових; шкідників плодів і насіння.

Сосна має певний комплекс хвороб і шкідників, які можуть на ній розвиватися. Традиційно лісівники завжди мали справу із кореневою губкою, опеньком, кількома видами лубоїдів та короїдів, які були супутніми до ослаблень сосни.

Проведені дослідження показали, що в соснових лісостанах Тернопільщини активізувалися кілька видів мікозних захворювань, котрі є збудниками некрозів (відмирання) гілок і суттєво ослаблюють дерева. А вже ослаблене дерево дає змогу розвиватися стовбуровим шкідникам. За останні кілька років одним із провідних серед них став верхівковий короїд [5].

Варто зазначити, що для кожної породи властива певна група комах-фітофагів, які іiі заселяють. При масовому розвитку ці рослиноїдні комахи можуть суттєво погіршувати стан дерев. До недавна верхівковий короїд особливої ролі не відігравав і в списку шкідників сосни був далеко не на перших ролях. Були згадки про його спалахи у 1930-х рр. на Поволжі і на сході України, але потім про нього ніхто нічого не чув. А зараз він став одним із основних шкідників сосни - стрімке його розмноження зафіксоване в Білорусі, Польщі, Словаччині, Румунії, Німеччині, Франції, Швейцарії [6].

Це зумовлено передусім тим, що погодні умови дуже сприяють його розвитку. За нормальних умов верхівковий короїд може дати одне-два покоління і утворити одне так зване сестринське покоління (коли дорослі особини вдруге заселяють ослаблені сосни). Посушливі погодні 
умови, які ми спостерігаємо протягом останнього часу, сприяють тому, що з'являються не два, а три покоління шкідників, два сестринські покоління, тобто цей короїд існує у лісі протягом усього вегетаційного періоду. Зимує він на стадії личинки, лялечки і дорослого жука, тому весною тільки-но погодні умови стануть сприятливими для його появи, верхівковий короїд одразу ж проявляється і заселяє сосни. Всихання куртин сосни охоплює від кількох особин до кількох сотень дерев, причому хвоя жовтіє дуже швидко, показуючи, що ці сосни вже «опрацьовані» верхівковим короїдом. Коли спостерігають пожовтіння хвої, то на той час нові покоління шкідника вже покинули ці осередки й атакують навколишні дерева, на яких поки що немає видимих ознак пошкоджень [7].

Верхівковому короїду супутні інші види: в нижній частині стовбура розвивається шестизубчастий короїд, великий сосновий лубоїд, синя соснова златка, у верхній - малий сосновий лубоїд та чотиризубчастий гравер, які також активізовують свою діяльність на пошкоджених рослинах. Проте погодні умови останніх років сприяють масовому розмноженню саме верхівкового короїда [8].

Поки людство існує, ми своєю діяльністю щодня міняємо світ і несемо відповідальність за ці зміни. Дерева не встигають за швидкими кліматичними коловоротами, відповідно, ми маємо берегти та стежити за їх здоров'ям, зрізати хворі та насаджуючи нові. Щоб зберегти позитивну тенденцію і збільшити озеленення, потрібно розпочати активну боротьбу із всиханням українських лісів, починаючи від законодавчих змін до змін в структурі управління лісовим господарством.

\section{Література:}

1. Лісові ресурси світу та проблеми, пов'язані з їх використанням [Електронний ресурс] - Режим доступу: https://osvita.ua/vnz/reports/ geograf/23469/

2. Лісові ресурси України [Електронний ресурс] - Режим доступу: https://osvita.ua/vnz/reports/ecology/21160/

3. Загальна характеристика Тернопільської області [Електронний pecypc] - Режим доступу: https://zachystemisto.te.ua/ternopil/general/

4. Шкідники лісу [Електронний ресурс] - Режим доступу: http://orativska.gromada.org.ua/more_news/1562239267/

5. Вплив короїдів на ліси [Електронний ресурс] - Режим доступу: https://cutt.ly/nhrVPem 
6. Поступове зникнення сосни в Україні [Електронний ресурс] Режим доступу: https://cutt.ly/2hrV60r

7. Державне агентство лісових ресурсів України [Електронний pecypc] - Режим доступу: https://cutt.ly/0hrBxCN

8. Небезпечний короїд продовжує знищувати ліси [Електронний pecypc] - Режим доступу: https://cutt.ly/2hrBT8R

DOI https://doi.org/10.30525/978-9934-26-006-3-20

\title{
МОРФОМЕТРИЧНІ ПАРАМЕТРИ HERACLEUM SOSNOWSKYI MANDEN В УМОВАХ УРБОЕКОСИСТЕМИ ІВАНО-ФРАНКІВСЬКА
}

\author{
Різничук Н. I. \\ кандидат біологічних наук, дочент, \\ дочент кафедри біології та екології \\ ДВНЗ «Прикарпатський національний університет \\ імені Василя Стефаника» \\ Бабак О. В. \\ аспірант кафедри біології та екології \\ ДВНЗ «Прикарпатський національний університет \\ імені Василя Стефаника» \\ Васечко Л. І. \\ методист факультету природничих наук \\ ДВНЗ «Прикарпатський національний університет \\ імені Василя Стефаника» \\ м. Івано-Франківськ, Україна
}

Загальною морфологічною ознакою Heracleum sosnowskyi Manden в умовах урбанізованого середовища $є$ зменшення площі вегетуючої поверхні, що можна розглядати як адаптивну ознаку, направлену на зменшення площі контакту з забрудненим аерогенним середовищем. Інтенсивність прояву вказаної тенденції визначається рівнем антропогенного пресингу на конкретні біотопи урбоекосистеми ІваноФранківська. Вказаний ефект також може бути спричинений механічним ушкодженням рослини внаслідок систематичного 